American J. of Engineering and Applied Sciences 1 (4): 252-259, 2008

ISSN 1941-7020

(C) 2008 Science Publications

\title{
MAM-An Aquivalence-based Dynamic Mass Balance Model for the Fate of Non-Volatile Organic Chemicals in the Agricultural Environment
}

\author{
${ }^{1}$ Mohammad A. Batiha, ${ }^{1}$ Abdul Amir H. Kadhum, ${ }^{1}$ Abu Bakar Mohamad, ${ }^{1}$ Mohd S. Takriff, \\ ${ }^{1}$ Zahedi Fisal, ${ }^{1}$ Wan Ramli W. Daud and ${ }^{2}$ Marwan M. Batiha \\ ${ }^{1}$ Department of Chemical and Process Engineering, Faculty of Engineering, \\ Universiti Kebangsaan Malaysia, 43600 UKM Bangi, Selangor D.E., Malaysia \\ ${ }^{2}$ Department of Chemical Engineering, Faculty of Mining and Environmental Engineering, \\ Al-Hussein Bin Talal University, Ma`an, Jordan
}

\begin{abstract}
A Multimedia Agricultural Model (MAM) for predicting the fate and transport of NonVolatile Organic Chemicals (NVOCs) in the agricultural environment was presented. It is an expanded and modified version of the three compartmental model introduced by Batiha and co-authors in 2007, which is an aquivalence-based level IV. MAM considered five environmental compartments to include the air, water, soil, sediment and vegetation. It calculates the complete steady-state mass budgets for the air, water and particulate organic carbon between the model compartments. MAM compartments were connected by advective and intermedia transport processes. Degradation can take place in every compartment. The mass balances for each of the compartments result in a system of five differential equations, solved numerically to yield estimates of concentrations, masses, transport fluxes and reaction rates as a function of time. All the equations required for MAM calculations were provided.
\end{abstract}

Key words: Agro-ecosystem, MAM, NVOCs, sediment, vegetation

\section{INTRODUCTION}

It is becoming evident that vegetations play an important role in the environmental fate of many organic compounds ${ }^{[1-4]}$. It is clearly an important aspect of the agricultural environment since approximately $97 \%$ of the plantations land surface is covered by vegetation. Moreover, the total leave surface area may exceed by factors of up to 20 the ground area on which plants grows ${ }^{[5]}$. The total amount of cuticular material in temperate forests and agricultural plants communities may range from $180-1500 \mathrm{~kg}$ per hectare ${ }^{[6]}$. As a result of the high reactivity of some compounds on vegetation surface and the array of available deposition surfaces in vegetation canopies $^{[7]}$, it has been suggested that vegetation could be an important sink for organic compounds ${ }^{[8]}$.

Many authors ${ }^{[9-10]}$ have reported that the concentrations of organic chemicals in forest soils are higher than in agricultural soils. This phenomenon was explained by Horstmann et al. ${ }^{[1]}$ that the elevated levels of organic chemicals present in forest soils compared to agricultural soils are due to atmospheric deposition processes. Atmospheric pollutants can be transferred to vegetation canopies either through wet or dry deposition ${ }^{[12]}$. Wet deposition, can be expected to be similar to vegetated and non-vegetated land. Hence, the elevated deposition to vegetations must arise from dry deposition. McLachlan et al. ${ }^{[13]}$ have divided the dry deposition of organic chemicals to vegetations into three categories according to the volatility of the compound. For the relatively Non-Volatile Organic Chemicals (NVOCs), gaseous deposition is superseded in importance by dry-particle-bound deposition. Sehmel ${ }^{[14]}$ sub-divided the dry-particle-bound deposition into three processes: particle sedimentation, particle impaction and diffusion ${ }^{[15]}$. Whereas, for NVOCs, the diffusion process from the surface compartments to the atmosphere is neglected ${ }^{[16]}$. Moreover, the dominant mechanisms that convey chemicals transport from vegetation to soil are also occurring under wet (i.e., canopy throughfall) and dry (i.e., litterfall) conditions ${ }^{[2]}$.

The water-sediment interface is an active layer, which typically consists of $95 \%$ particles and is often highly in organic nature. It may consists of deposited particles and fecal material from water column ${ }^{[17]}$. The main transport processes within water-sediment interface layer are deposition, resuspension and sediment burial. Therefore, the inclusion of vegetation

Corresponding Author: Mohammad A. Batiha, Department of Chemical and Process Engineering, Universiti Kebangsaan Malaysia, 43600 UKM Bangi, Selangor D.E., Malaysia E-mail: mabatiha@yahoo.com 


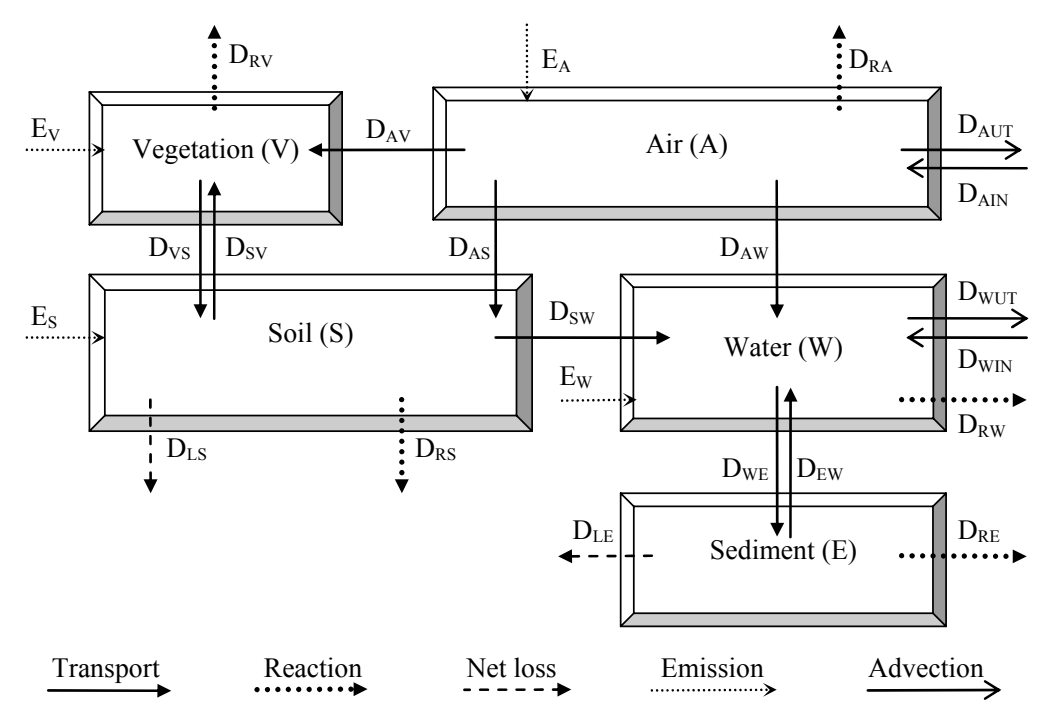

Fig. 1: Schematic representation of the environmental compartments and chemical fate processes in MAM

and sediment compartments into multimedia models for NVOCs is an important issue. This study follows up the preliminary findings, reported by Batiha et al.$^{[18]}$ and constitute on recent attempts to include vegetation and sediment compartments into multimedia aquivalencebased models at the dynamic conditions. Herewith, we have described the Multimedia Agricultural Model (MAM) and provided all the necessary equations for the model feasibility calculation.

Model structure: The main concepts of MAM have been presented in detail by Batiha et al. ${ }^{[18]}$. Hence, MAM is an aquivalence-based, dynamic (Level IV: unsteady-state, non-equilibrium with degradation, advection and inter-compartmental transfer) model. The MAM environment consists of up to five environmental compartments Fig. 1, namely, the Air (A), Water (W), Soil (S), Sediment (E) and Vegetation (V), which are believed to shape the agricultural environment. These compartments are linked by up to eight transport processes from $i$ to $j$ compartment $\left(D_{i j}, \mathrm{~m}^{3} \mathrm{~h}^{-1}\right)$. There are two possibilities through which NVOCs can enter the modeled environment: either by direct emission to compartment $\mathrm{i}\left(\mathrm{E}_{\mathrm{i}} \mathrm{mol} \mathrm{h}^{-1}\right)$ and/or by advection of air and water into the model domain $\left(\mathrm{D}_{\mathrm{AIN}}\right.$ and $\mathrm{D}_{\mathrm{WIN}}$, mol $\mathrm{h}^{-1}$ ). Once NVOCs is introduced to the environment, it can move amongst compartments and can be lost from each compartment $i$ through various transformation processes $\left(D_{R i}\right)$, leaching from soil to ground water $\left(D_{\mathrm{LS}}\right)$ and sediment burial $\left(\mathrm{D}_{\mathrm{LE}}\right)$. In addition, NVOCs can be lost by advection of air and water out of the model domain $\left(D_{\text {AUT }}\right.$ and $\left.D_{\text {WUT }}, \mathrm{m}^{3} \mathrm{~h}^{-1}\right)$.

\section{RESULTS AND DISCUSSION}

NVOCs transfer fluxes: Chemical movement in the environment is strongly associated with the movement of air, water and organic matter ${ }^{[19]}$. NVOCs advective inter-compartmental transfer fluxes are calculated as the product of a flux of a carrier phase (F) in units of $\mathrm{m}^{3} \mathrm{~h}^{-1}$, namely, air (AF), water (WF) and particulate organic carbon $(\mathrm{PF})$ and a NVOC concentration $(\mathrm{C}, \mathrm{mol}$ $\mathrm{m}^{-3}$ ) in similar phase. Solving the NVOC mass balance thus requires the constructions of mass balance for air, water and Particulate Organic Carbon (POC) within the modeled system. These fluxes were assumed to be constant in time. In the following, details are provided for the construction of mass balances for air, water and POC.

Mass balance of air: As has been discussed by Batiha et al. ${ }^{[18]}$, the mass balance for air is calculated as the volume of atmospheric compartment divided by the atmospheric residence time.

Mass balance for water: The water mass balance consistent set of up to 11 inter-compartmental water fluxes, WF in $\mathrm{m}^{3} \mathrm{~h}^{-1}$, between the modeled compartments Fig. 2. The water flux from air to the surface compartments by precipitation, $\mathrm{WF}_{\mathrm{AX}}$ (Eq. 1, 5 and 8 in Table 1), is estimated from the rain rate $\left(U_{R}, m\right.$ $\left.\mathrm{h}^{-1}\right)$ and the compartment surface area $\left(\mathrm{A}_{X}, \mathrm{~m}^{2}\right)$. Evaporation loss from the surface compartments, $\mathrm{WF}_{\mathrm{XA}}$ (Eq. 2, 6 and 9 in Table 1), is estimated by employing fractions $\phi_{\mathrm{X}}$ of the total water flow to a compartment $\mathrm{x}$ 
Am. J. Engg. \& Applied Sci., 1 (4): 252-259, 2008

Table 1: Equations used to calculate the water and POC fluxes between MAM compartments in units of $\mathrm{m}^{3} \mathrm{~h}^{-1}$

\begin{tabular}{|c|c|c|}
\hline Fluxes & & Equations \\
\hline \multicolumn{3}{|l|}{ I. Water fluxes: } \\
\hline 1. & Precipitation from air to vegetation & $\mathrm{WF}_{\mathrm{AV}}=\mathrm{U}_{\mathrm{R}} \mathrm{A}_{\mathrm{V}}$ \\
\hline 2. & Evaporation from vegetation to air & $\mathrm{WF}_{\mathrm{VA}}=\phi_{\mathrm{V}}\left(\mathrm{WF}_{\mathrm{AV}}+\mathrm{WF}_{\mathrm{SV}}\right)$ \\
\hline 3. & Throughfall from vegetation to soil & $\mathrm{WF}_{\mathrm{VS}}=\left(1-\phi_{\mathrm{V}}\right)\left(\mathrm{WF}_{\mathrm{AV}}+\mathrm{WF}_{\mathrm{SV}}\right)$ \\
\hline 4. & Rainsplash from soil to vegetation & $\mathrm{WF}_{\mathrm{SV}}=\phi_{\mathrm{RS}} \mathrm{WF}_{\mathrm{AS}}$ \\
\hline 5. & Precipitation from air to soil & $\mathrm{WF}_{\mathrm{AS}}=\mathrm{U}_{\mathrm{R}} \mathrm{A}_{\mathrm{S}}$ \\
\hline 6. & Evaporation from soil to air & $\mathrm{WF}_{\mathrm{SA}}=\phi_{\mathrm{S}}\left(\mathrm{WF}_{\mathrm{AS}}+\mathrm{WF}_{\mathrm{VS}}\right)$ \\
\hline 7. & Runoff and leaching from soil to water & $\mathrm{WF}_{\mathrm{SW}}=\left(1-\phi_{\mathrm{S}}-\mathrm{WF}_{\mathrm{SV}}\right)\left(\mathrm{WF}_{\mathrm{AS}}+\mathrm{WF}_{\mathrm{VS}}\right)$ \\
\hline 8. & Precipitation from air to water & $\mathrm{WF}_{\mathrm{AW}}=\mathrm{U}_{\mathrm{R}} \mathrm{A}_{\mathrm{W}}$ \\
\hline 9. & Evaporation from water to air & $\mathrm{WF}_{\mathrm{WA}}=\phi_{\mathrm{W}}\left(\mathrm{WF}_{\mathrm{AW}}+\mathrm{WF}_{\mathrm{SW}}\right)$ \\
\hline 10. & Water flow from water to the outside & $\mathrm{WF}_{\mathrm{UT}}=\left(1-\phi_{\mathrm{W}}\right)\left(\mathrm{WF}_{\mathrm{AW}}+\mathrm{WF}_{\mathrm{SW}}\right)\left(1+\mathrm{f}_{\mathrm{UT}}\right)$ \\
\hline 11. & Water flow from the outside to water & $\mathrm{WF}_{\mathrm{IN}}=\left(1-\phi_{\mathrm{W}}\right)\left(\mathrm{WF}_{\mathrm{AW}}+\mathrm{WF}_{\mathrm{SW}}\right) \mathrm{f}_{\mathrm{UT}}$ \\
\hline \multicolumn{3}{|l|}{ II. POC fluxes: } \\
\hline 12. & POC inflow from soil to water & $\mathrm{PF}_{\mathrm{SW}}=\mathrm{WF}_{\mathrm{SW}} v_{\mathrm{SS}} / \rho_{\mathrm{OC}}$ \\
\hline 13. & $\mathrm{POC}$ production in water & $\mathrm{PF}_{\mathrm{W} \text { pro }}=\mathrm{P}_{\mathrm{W}} \mathrm{A}_{\mathrm{W}} /\left(\rho_{\mathrm{OC}} 8760\right)$ \\
\hline 14. & POC mineralization in water & $\mathrm{PF}_{\mathrm{Wmin}_{\min }}=\mathrm{PF}_{\mathrm{Wpro}} \phi_{\mathrm{Wmin}}$ \\
\hline \multirow{2}{*}{15.} & \multirow{2}{*}{ POC concentration in water } & $\mathrm{C}_{\mathrm{PW}}=\frac{\mathrm{PF}_{\mathrm{SW}}+\mathrm{PF}_{\mathrm{Wpro}}-\mathrm{PF}_{\mathrm{Wmin}}+\left(\mathrm{WF}_{\mathrm{IN}} \mathrm{C}_{\mathrm{PIN}}\right) / \rho_{\mathrm{OC}}}{\Gamma \mathrm{WT}}$ \\
\hline & & {$\left[\mathrm{WF}_{\mathrm{UT}}+\left(1-\phi_{\mathrm{res}}\right) \mathrm{U}_{\mathrm{sed}} \mathrm{A}_{\mathrm{E}}\right] / \rho_{\mathrm{OC}}$} \\
\hline 16. & POC sedimentations from water to sediment & $\mathrm{PF}_{\mathrm{WE}}=v_{\mathrm{sed}} \mathrm{A}_{\mathrm{W}} \mathrm{C}_{\mathrm{pw}} / \mathrm{P}_{\mathrm{OC}}$ \\
\hline 17. & POC resuspension to water from sediment & $\mathrm{PF}_{\mathrm{EW}}=\phi_{\mathrm{res}} \mathrm{v}_{\mathrm{sed}} \mathrm{A}_{\mathrm{W}} \mathrm{C}_{\mathrm{PW}} / \mathrm{P}_{\mathrm{OC}}$ \\
\hline 18. & POC burial in sediment & $\mathrm{PF}_{\mathrm{LE}}=\mathrm{A}_{\mathrm{W}} v_{\mathrm{SE}} v_{\text {bur }} v_{\mathrm{OE}}$ \\
\hline 19. & POC mineralization in sediment & $\mathrm{PF}_{\mathrm{Emin}}=\left(\mathrm{PF} \mathrm{WE}_{\mathrm{WE}}-\mathrm{PF} \mathrm{F}_{\mathrm{EW}}\right) \phi_{\mathrm{Emin}}$ \\
\hline
\end{tabular}

Note: $U_{R}$ is the rainfall rate, $\mathrm{m}^{3} \mathrm{~h}^{-1}, \mathrm{~A}_{\mathrm{X}}$ is the surface area of compartment $\mathrm{x}, \mathrm{m}^{2}, \phi_{\mathrm{x}}$ is the fraction of precipitation to compartment $\mathrm{x}$ that evaporates from that compartment, $\phi_{\mathrm{RS}}$ is the fraction of raindrop water reflected after reaching the soil surface to vegetation, $f_{\mathrm{UT}}$ is the factor by which water is increased by inflow from the outside flux, $v_{\mathrm{SE}}, v_{\mathrm{OE}}$ and $v_{\mathrm{SS}}$ are the volume fraction of solids in sediment, of organic carbon in sediment solids and of solids in soil, respectively, $\rho_{\mathrm{OC}}$ is the density of organic carbon, $\mathrm{g} \mathrm{m}^{-3}, \mathrm{P}_{\mathrm{W}}$ is the primary productivity in water, $\mathrm{g}$ carbon $/ \mathrm{m}^{2}$ a, $\phi_{\mathrm{Wmin}}$ and $\phi_{\mathrm{Emin}}$ are the fraction of net POC input to water and sediment compartments, respectively, that is mineralized, $\mathrm{C}_{\mathrm{PIN}}$ is the concentration of POC in the water flow from the outside, $\mathrm{g} \mathrm{m}^{-3}, \mathrm{v}_{\text {sed }}$ and $v_{\text {bur }}$ are the POC sedimentation and burial velocities in sediment, respectively, $\phi_{\mathrm{res}}$ is the fraction of POC deposition that is resuspended

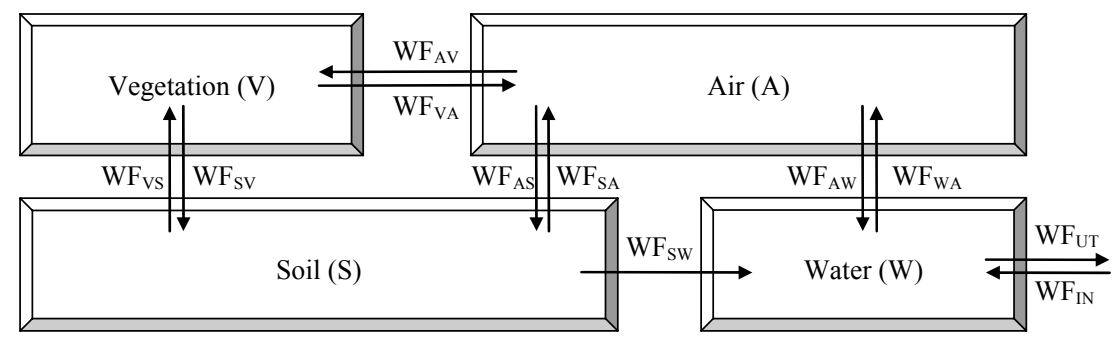

Fig. 2: Water fluxes between MAM compartments

that evaporates from that compartment. The water flux from vegetation to the soil by throughfall, $\mathrm{WF}_{\mathrm{VS}}$ (Eq. 3 in Table 1), is derived as the balance of the remaining fraction of precipitation to vegetation that fall to soil from evaporation loss. The water flux from the soil to vegetation by rainsplash, $\mathrm{WF}_{\mathrm{SV}}$ (Eq. 4 in Table 1), is estimated by employing fractions $\phi_{\mathrm{RS}}$ of the raindrop water reflected after reaching the soil surface to vegetation. The run-off and leaching flux from soil to the water compartment, $\mathrm{WF}_{\mathrm{SW}}$ (Eq. 7 in Table 1), is derived as the balance of the remaining fraction of precipitation plus water throughfall from the vegetation to soil obtained from evaporation plus rainsplash losses. The net flow between water compartment and the outside, $\mathrm{WF}_{\mathrm{UT}}$ and $\mathrm{WF}_{\mathrm{IN}}$ (Eq. 10 and 11 in Table 1), is estimated employing the factor $\left(f_{\mathrm{UT}}\right)$ by which water is increased by inflow from the outside flux.

POC mass balance: The POC fluxes illustrated in Eq. 12-15 in Table 1, has been discussed in detail by Batiha et al. ${ }^{[18]}$. Only the calculation of the new included POC fluxes over the sediment compartment needed for the construction of POC mass balance is discussed in this study Fig. 3. These fluxes are POC sedimentations from 
Am. J. Engg. \& Applied Sci., 1 (4): 252-259, 2008

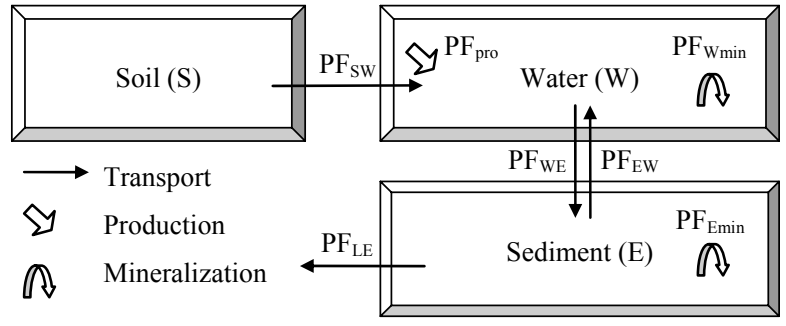

Fig. 3: POC fluxes between MAM compartments

water to sediment, POC resuspension to water from sediment, POC burial in sediment, and POC mineralization in sediment (Eq. 16-19 in Table 1, respectively). Whereas, the user-defined parameters are the POC sedimentation and burial velocities in sediment, $v_{\text {sed }}$ and $v_{\text {bur }}$, respectively, the fraction of POC deposition that is resuspended $\left(\phi_{\mathrm{res}}\right)$, the density of organic carbon in $\mathrm{g} \mathrm{m}^{-3}\left(\rho_{\mathrm{OC}}\right)$, the fraction of net POC input to sediment compartment $\left(\phi_{\text {Emin }}\right)$, the volume fraction of solids in sediment $\left(v_{\mathrm{SE}}\right)$ and the volume fraction of organic carbon in sediment solids $\left(v_{\mathrm{OE}}\right)$.

Description of chemical fate: Chemical fate in the MAM (Level IV calculations) is expressed in the form of an unsteady-state mass balance equation for each of the five model compartments Table 2 . These equations have the general form shown below and are formulated in terms of aquivalence $\left(\mathrm{q}_{\mathrm{i}}, \mathrm{mol} \mathrm{m}^{-3}\right)$, employing the concepts of Z-values (dimensionless) to describe the phase partitioning and D-values $\left(\mathrm{m}^{3} \mathrm{~h}^{-1}\right)$ to describe the chemical fate processes. Due to the fluctuation of some environmental parameters with season, the Z- and Dvalues are functions of time $(\mathrm{t})$ :

$$
\begin{aligned}
& \frac{d\left(q_{i} Z_{i} V_{i}\right)}{d t}=E_{i}(t)+\sum_{j}\left(D_{j i}(t) q_{j}(t)\right) \\
& -q_{i}(t)\left(D_{i}(t)+\sum_{j} D_{i j}(t)\right)
\end{aligned}
$$

where $q_{i}$ is the aquivalence in compartment $i$ at time $t$ in mol m${ }^{-3}, Z_{i}(t)$ the dimensionless partitioning capacity of compartment $i$ at time $t, V_{i}$ the volume of compartment $\mathrm{i}$ in $\mathrm{m}^{3}, \mathrm{E}_{\mathrm{i}}(\mathrm{t})$ the direct emission rate into compartment $\mathrm{i}$ at time $\mathrm{t}$ in $\mathrm{mol} \mathrm{h}^{-1}, \mathrm{D}_{\mathrm{ji}}(\mathrm{t})$ the $\mathrm{D}$-value describing transport from compartment $i$ to $j$ at time $t$ in $\mathrm{m}^{3} \mathrm{~h}^{-1}$, $\mathrm{D}_{\mathrm{i}}(\mathrm{t})$ the $\mathrm{D}$-value describing loss processes from compartment $i$ at time $t$ in $\mathrm{m}^{3} \mathrm{~h}^{-1}$.

The compartments volumes are constant, therefore, the equations can be rewritten as partial differential equations:

$$
\begin{aligned}
\frac{\delta q_{i}}{\delta t}= & Z_{i}(t) \times V_{i}+\frac{\delta Z_{i}}{\delta t} q_{i}(t) \times V_{i} \\
= & E_{i}(t)+\sum_{j}\left(D_{j i}(t) \times q_{j}(t)\right)-q_{i}(t) \\
& \left(D_{i}(t)+\sum_{j} D_{i j}(t)\right)
\end{aligned}
$$

Substituting the differentials by finite differences:

$$
\begin{aligned}
& \frac{\mathrm{q}_{i}(\mathrm{t}+\Delta \mathrm{t})-\mathrm{q}_{i}(\mathrm{t})}{\Delta \mathrm{t}} \times \mathrm{Z}_{\mathrm{i}}(\mathrm{t}) \times \mathrm{V}_{\mathrm{i}}+ \\
& \frac{\mathrm{Z}_{\mathrm{i}}(\mathrm{t}+\Delta \mathrm{t})-\mathrm{Z}_{\mathrm{i}}(\mathrm{t}-\Delta \mathrm{t})}{2 \Delta \mathrm{t}} \mathrm{q}_{\mathrm{i}}(\mathrm{t}) \times \mathrm{V}_{\mathrm{i}} \\
& =\mathrm{E}_{\mathrm{i}}(\mathrm{t})+\sum_{j}\left(D_{j i}(\mathrm{t}) \times \mathrm{q}_{j}(\mathrm{t})\right) \\
& -\mathrm{q}_{\mathrm{i}}(\mathrm{t})\left(D_{\mathrm{i}}(\mathrm{t})+\sum_{j} D_{i j}(\mathrm{t})\right)
\end{aligned}
$$

Z-values are independent of the aquivalences and can be calculated for time $t+\Delta t$. The time course of the aquivalences in all compartments can thus be calculated iteratively using:

$$
q_{i}(t+\Delta t)=q_{i}(t)+\frac{\Delta t}{Z_{i}(t) \times V_{i}}\left(\begin{array}{l}
E_{i}(t)+\sum_{j}\left(D_{j i}(t) \times q_{j}(t)\right) \\
-q_{i}(t)\left(D_{i}(t)+\sum_{j} D_{i j}(t)\right) \\
-\frac{Z_{i}(t+\Delta t)-Z_{i}(t-\Delta t)}{2 \Delta t} q_{i}(t) \times V_{i}
\end{array}\right)
$$

Estimating aquivalences in all MAM compartments as a function of time, the intermedia fluxes between MAM compartments, reaction rate, chemical residence time and chemical concentration in each compartment can be deduced. In the following context, the details of how the various Z- and D-values can be calculated in the MAM are provided.

Description of phase partitioning: Equilibrium phase partitioning in MAM as is typical for aquivalence-based models are expressed in terms of Z-values or the compartment partitioning capacities. The $Z$-values for sediment and vegetation compartments $\left(Z_{\mathrm{E}}\right.$ and $\left.Z_{V}\right)$ are described by Eq. 1 and 2, respectively:

$$
\begin{aligned}
& Z_{\mathrm{E}}=\mathrm{Z}_{\mathrm{W}} \rho_{\mathrm{E}} \mathrm{K}_{\mathrm{EW}} / 1000 \\
& Z_{\mathrm{V}}=Z_{\mathrm{W}} \mathrm{K}_{\mathrm{CW}}
\end{aligned}
$$

where $Z_{\mathrm{W}}$ is the partitioning capacity of water compartment, $\rho_{\mathrm{E}}$ is the sediment density and $\mathrm{K}_{\mathrm{EW}}$ and 
Table 2: Mass balance equations for each MAM compartment

\begin{tabular}{ll}
\hline Compartment & Mass balance equations \\
\hline Air & $\mathrm{d}\left(\mathrm{V}_{\mathrm{A}} \mathrm{Z}_{\mathrm{BA}} \mathrm{q}_{\mathrm{A}}\right) / \mathrm{dt}=\left(\mathrm{E}_{\mathrm{A}}+\mathrm{D}_{\mathrm{AIN}}\right)-\left(\mathrm{D}_{\mathrm{AUT}}+\mathrm{D}_{\mathrm{RA}}+\mathrm{D}_{\mathrm{AV}}+\mathrm{D}_{\mathrm{AS}}+\mathrm{D}_{\mathrm{AW}}\right) \mathrm{q}_{\mathrm{A}}$ \\
Water & $\mathrm{d}\left(\mathrm{V}_{\mathrm{W}} Z_{\mathrm{BW}} \mathrm{q}_{\mathrm{W}}\right) / \mathrm{dt}=\left(\mathrm{E}_{\mathrm{W}}+\mathrm{D}_{\mathrm{WIN}}+\mathrm{D}_{\mathrm{SW}} \mathrm{q}_{\mathrm{S}}+\mathrm{D}_{\mathrm{EW}} \mathrm{q}_{\mathrm{A}}+\mathrm{D}_{\mathrm{EW}} \mathrm{q}_{\mathrm{E}}\right)-\left(\mathrm{D}_{\mathrm{WUT}}+\mathrm{D}_{\mathrm{WE}}+\mathrm{D}_{\mathrm{RW}}\right) \mathrm{q}_{\mathrm{W}}$ \\
Soil & $\mathrm{d}\left(\mathrm{V}_{\mathrm{S}} \mathrm{Z}_{\mathrm{BS}} \mathrm{q}_{\mathrm{S}}\right) / \mathrm{dt}=\left(\mathrm{E}_{\mathrm{S}}+\mathrm{D}_{\mathrm{AS}} \mathrm{q}_{\mathrm{A}}+\mathrm{D}_{\mathrm{VS}} \mathrm{q}_{\mathrm{V}}\right)-\left(\mathrm{D}_{\mathrm{SV}}+\mathrm{D}_{\mathrm{SW}}+\mathrm{D}_{\mathrm{RS}}+\mathrm{D}_{\mathrm{LS}}\right) \mathrm{q}_{\mathrm{S}}$ \\
Sediment & $\mathrm{d}\left(\mathrm{V}_{\mathrm{E}} \mathrm{Z}_{\mathrm{BE}} \mathrm{q}_{\mathrm{E}}\right) / \mathrm{dt}=\left(\mathrm{D}_{\mathrm{EW}} \mathrm{q}_{\mathrm{W}}\right)-\left(\mathrm{D}_{\mathrm{EW}}+\mathrm{D}_{\mathrm{RE}}+\mathrm{D}_{\mathrm{LE}}\right) \mathrm{q}_{\mathrm{E}}$ \\
Vegetation & $\mathrm{d}\left(\mathrm{V}_{\mathrm{V}} \mathrm{Z}_{\mathrm{BV}} \mathrm{q}_{\mathrm{V}}\right) / \mathrm{dt}=\left(\mathrm{E}_{\mathrm{V}}+\mathrm{D}_{\mathrm{SV}} \mathrm{q}_{\mathrm{S}}+\mathrm{D}_{\mathrm{AV}} \mathrm{q}_{\mathrm{A}}\right)-\left(\mathrm{D}_{\mathrm{VS}}+\mathrm{D}_{\mathrm{RV}}\right) \mathrm{q}_{\mathrm{V}}$ \\
\hline
\end{tabular}

$\mathrm{K}_{\mathrm{CW}}$ are the sediment- and cuticle-water partition coefficients, respectively. The $\mathrm{K}_{\mathrm{CW}}$ is the parameter describing the tendency of environmental chemicals to accumulate in the cuticle phase in an ecosystem as well as on a single leaf or fruit scale. Based on the available data, one of the following quantitative structureactivity relationship models can be used to calculate the $\mathrm{K}_{\mathrm{CW}}{ }^{[20-21]}$ :

$$
\begin{aligned}
& \log \mathrm{K}_{\mathrm{CW}}=0.057+0.970 \log \mathrm{K}_{\mathrm{OW}} \\
& \log \mathrm{K}_{\mathrm{CW}}=1.118-0.569 \log \mathrm{S} \\
& \log \mathrm{K}_{\mathrm{CW}}=0.37+1.31^{3} \chi^{\mathrm{v}}-1.49 \mathrm{~N}_{\mathrm{aliph}}^{\mathrm{OH}}
\end{aligned}
$$

Where $\mathrm{K}_{\mathrm{OW}}$ is the octanol-water partition coefficient, $\mathrm{S}$ the water solubility, ${ }^{3} \chi^{\mathrm{v}}$ the valence third-order molecular connectivity index that calculated from the non-hydrogen part of the molecule and $\mathrm{N}_{\text {aliph }}^{\mathrm{OH}}$ the number of aliphatic hydroxy groups.

The bulk $Z$-value for sediment and vegetation compartments $\left(\mathrm{Z}_{\mathrm{BE}}\right.$ and $\left.\mathrm{Z}_{\mathrm{BV}}\right)$ is calculated by Eq. 6 and 7 , respectively:

$$
\begin{aligned}
& Z_{\mathrm{BE}}=\left(1-v_{\mathrm{E}}\right) \mathrm{Z}_{\mathrm{E}}+v_{\mathrm{E}} v_{\mathrm{OE}} \mathrm{Z}_{\mathrm{P}} \\
& \mathrm{Z}_{\mathrm{BV}}=v_{\mathrm{AV}} \mathrm{Z}_{\mathrm{A}}+v_{\mathrm{WV}} \mathrm{Z}_{\mathrm{W}}+v_{\mathrm{CV}} \mathrm{Z}_{\mathrm{V}}
\end{aligned}
$$

where $v_{\mathrm{E}}$ is the volume fraction of solids in sediment, $v_{\mathrm{OE}}$ is the volume fraction of organic carbon in sediment solids, $Z_{\mathrm{P}}$ is the $Z$-value for particulate organic carbon and $v_{\mathrm{AV}}, v_{\mathrm{WV}}$ and $v_{\mathrm{CV}}$ are the volume fraction of air, water and cuticle in vegetation, respectively.

Description of chemical fate processes: Transport, loss and transformation processes in aquivalence-based models are described with the help of D-values in units of $\mathrm{m}^{3} \mathrm{~h}^{-1}$. The present model adds the D-values for sediment and vegetation compartments to those Dvalues previously described by Batiha et al. ${ }^{[18]}$ for air, water and soil. The additional estimated D-values are drawn upon on recent modeling published papers ${ }^{[2,19,22-}$ 23]. The transport and transformation processes from and to sediment and vegetation compartments are discussed below and D-values are listed in Table 3.

As MAM is intended to be applicable for NVOCs, the diffusion process from plant surface to air was neglected. Advective processes from air to vegetation are the wet and dry particle deposition. The D-value for wet deposition of particles to vegetation is given by Eq. 3 in Table 3. In this equation, the wet deposition interception fraction $\left(\mathrm{If}_{\mathrm{W}}\right)$ depends on the leaf area index (LAI) in units of $\mathrm{m}^{2}$ leaves per $\mathrm{m}^{2}$ land, the rainfall rate $\left(\mathrm{U}_{\mathrm{R}}, \mathrm{m} \mathrm{h}^{-1}\right)$ and the canopy water storage capacity $\left(\mathrm{S}_{\mathrm{bl}}\right)$, and can be calculated from Müller and Pröhl $^{[24]}$ as follows:

$$
\text { If }_{\mathrm{w}}=\mathrm{S}_{\mathrm{bl}} \mathrm{LAI} \exp \left(\frac{-\ln \left(2 \mathrm{U}_{\mathrm{R}}\right)}{3 \mathrm{~S}_{\mathrm{bl}}}\right)
$$

The D-value for dry particle deposition to vegetation is given by Eq. 4 in Table 3. The dry deposition interception fraction $\left(\mathrm{If}_{\mathrm{d}}\right)$ is calculated from plant biomass as described by Whicker and Kirchner ${ }^{[25]}$,

$$
\text { If }_{\mathrm{d}}=1-\exp \left(-2.8 \text { bio }_{\text {inv }}\right)
$$

where bio $_{\text {inv }}$ is the plant dry mass inventory (kg dry mass $\mathrm{m}^{-2}$ ). Summation of D-values for wet and dry particle deposition (Eq. 3 and 4 in Table 3 ) give the overall D-value for air to vegetation.

The dominant transport mechanisms of NVOCs from vegetation to soil are also occurring under wet (canopy throughfall) and dry (litterfall) conditions. Litterfall is the process of vegetation foliage falling to the ground as a result of shedding of leaves and vegetation death and controlled by a first order rate constant $\left(\mathrm{k}_{\mathrm{LF}}\right)$. The $\mathrm{k}_{\mathrm{LF}}$ is assumed by Bennett et al. ${ }^{[22]}$ to be equal to one divided by the length of the growing season. The D-value for this process is given by Eq. 6 in Table 3. Canopy throughfall (Eq. 7 in Table 3) is the process of washing out of contaminant sorbed onto vegetations by precipitation, which is calculated as the product of the water flux from vegetation to soil $\left(\mathrm{WF}_{\mathrm{VS}}\right.$, $\mathrm{m}^{3} \mathrm{~h}^{-1}$ ) and the vegetation bulk $\mathrm{Z}$-value $\left(\mathrm{Z}_{\mathrm{BV}}\right)$. Summation of D-values for canopy throughfall and litterfall yield the total D-value for the transport mechanisms from the vegetation to the soil. 
Am. J. Engg. \& Applied Sci., 1 (4): 252-259, 2008

Table 3: D-values formulation specific to MAM in units of $\mathrm{m}^{3} \mathrm{~h}^{-1}$

\begin{tabular}{|c|c|c|c|c|}
\hline \multicolumn{5}{|c|}{ Compartment } \\
\hline From & To & & Process & Equation \\
\hline Vegetation & Air & 1. & Chemical diffusion from foliage & $\mathrm{D}_{\mathrm{VA}}=0$ \\
\hline \multirow[t]{3}{*}{ Air } & Vegetation & 2. & Total & $\mathrm{D}_{\mathrm{AV}}=\mathrm{D}_{\mathrm{WD}}+\mathrm{D}_{\mathrm{DD}}$ \\
\hline & & 3. & Wet deposition of particles & $\mathrm{D}_{\mathrm{WD}}=\mathrm{WF}_{\mathrm{AV}} \mathrm{If}_{\mathrm{w}} \mathrm{Z}_{\mathrm{BR}}$ \\
\hline & & 4. & Dry deposition of particles & $D_{D D}=A_{V} I f_{d} U_{Q} v_{Q} Z_{Q}$ \\
\hline \multirow[t]{3}{*}{ Vegetation } & Soil & 5. & Total & $\mathrm{D}_{\mathrm{VS}}=\mathrm{D}_{\mathrm{CT}}+\mathrm{D}_{\mathrm{LF}}$ \\
\hline & & 6. & Litterfall & $D_{\mathrm{LF}}=V_{\mathrm{V}} \mathrm{k}_{\mathrm{LF}} Z_{\mathrm{BV}}$ \\
\hline & & 7. & Canopy throughfall & $\mathrm{D}_{\mathrm{CT}}=\mathrm{WF}_{\mathrm{VS}} \mathrm{Z}_{\mathrm{BV}}$ \\
\hline Soil & Vegetation & 8. & Rain splash & $\mathrm{D}_{\mathrm{VS}}=\mathrm{WF}_{\mathrm{SV}} \mathrm{Z}_{\mathrm{BS}}$ \\
\hline Water & Sediment & 9. & Total & $D_{\mathrm{WE}}=\mathrm{D}_{\mathrm{diff}}+\mathrm{D}_{\mathrm{dep}}$ \\
\hline \multirow[t]{9}{*}{ Sediment } & Water & 10. & Total & $\mathrm{D}_{\mathrm{EW}}=\mathrm{D}_{\mathrm{diff}}+\mathrm{D}_{\mathrm{res}}$ \\
\hline & & 11. & Diffusion across the water sediment interface & $\mathrm{A}_{\mathrm{W}}$ \\
\hline & & 11. & 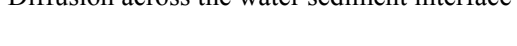 & $\ln (2) h_{E}$ \\
\hline & & & & $k_{\mathrm{EW}} \mathrm{Z}_{\mathrm{W}} \quad \mathrm{Z}_{\mathrm{w}}\left[\mathrm{B}_{\mathrm{W}}\left(1-v_{\mathrm{E}}\right)^{1.5}+\mathrm{B}_{\mathrm{WE}}\right]+\mathrm{B}_{\mathrm{PE}} v_{\mathrm{OE}} \mathrm{Z}_{\mathrm{P}}$ \\
\hline & & 12. & Deposition & $\mathrm{D}_{\mathrm{dep}}=\mathrm{PF}_{\mathrm{WE}} Z_{\mathrm{P}}$ \\
\hline & & 13. & Resuspension & $D_{\text {res }}=P F_{E W} Z_{P}$ \\
\hline & & 14. & Sediment burial & $D_{L E}=P F_{L E} Z_{P}$ \\
\hline & & 15. & Degradation in vegetation & $D_{R V}=V_{V} k_{R V} Z_{V}$ \\
\hline & & 16. & Degradation in sediment & $D_{R E}=V_{E} k_{R E} Z_{E}$ \\
\hline
\end{tabular}

Notes: $A_{V}$ and $A_{W}$ are the surface area of vegetation and water compartments, $m^{2}, I_{w}$ and $I_{d}$ are the canopy wet and dry interception fraction, $U_{Q}$ is the dry deposition velocity, $\mathrm{m} \mathrm{h}^{-1} v_{\mathrm{Q}}, v_{\mathrm{OE}}$ and $v_{\mathrm{E}}$ are the volume fraction of aerosol in air, of organic carbon in sediment and of solids in sediment, respectively, $V_{V}$ and $V_{E}$ are the volume of vegetation and sediment compartments, $\mathrm{m}^{3}, \mathrm{k}_{\mathrm{LF}}$ is the litterfall rate constant, $\mathrm{h}^{-1}$, $\mathrm{k}_{\mathrm{EW}}$ is the mass transfer coefficient for diffusion across benthic boundary layer, $\mathrm{m} \mathrm{h}^{-1}, \mathrm{~h}_{\mathrm{E}}$ is the depth of sediment compartment, $\mathrm{m}, \mathrm{B}_{\mathrm{W}}$ is the molecular diffusivity in water, $\mathrm{m}^{2} \mathrm{~h}^{-1}, \mathrm{~B}_{\mathrm{WE}}$ is the bioirrigation diffusivity of sediment pore water, $\mathrm{m}^{2} \mathrm{~h}^{-1}$, $\mathrm{B}_{\mathrm{PE}}$ is the bioturbation diffusivity of sediment solids, $\mathrm{m}^{2} \mathrm{~h}^{-1}$ and $\mathrm{k}_{\mathrm{RV}}$ and $\mathrm{k}_{\mathrm{RE}}$ are the vegetation and sediment degradation rate constants, $\mathrm{h}^{-1}$

Rainsplash, which is the only transport mechanism from soil to vegetation considered, is based on the concept that once lifted off by the raindrop impact, the particle-sorbed contaminant in soil entrained into the splash droplets travel to vegetation. The D-value for this mechanism (Eq. 8 in Table 3) is calculated as a product of the water flux from soil to vegetation $\left(\mathrm{WF}_{\mathrm{SV}}\right.$, $\left.\mathrm{m}^{3} \mathrm{~h}^{-1}\right)$ and the soil bulk $\mathrm{Z}$-value $\left(\mathrm{Z}_{\mathrm{BV}}\right)$.

The processes contribute the exchange of contaminants across the water-sediment interface as described by Wania et al. ${ }^{[19]}$ are two advective and four different diffusive processes. The advective processes are physical sedimentation or deposition and resuspension of contaminants sorbed to POC (Eq. 12 and 13 in Table 3), described using the POC transport rates $\mathrm{PF}_{\mathrm{WE}}$ and $\mathrm{PF}_{\mathrm{EW}}$ in $\mathrm{m}^{3} \mathrm{~h}^{-1}$ derived in Table 1. The overall diffusive process, which may act in either direction, is described as follows. On the waterside there is a resistance to transfer through the stagnant benthic boundary layer above the sediment surface, quantified using a benthic boundary layer mass transfer coefficient, $\mathrm{k}_{\mathrm{EW}}$ in $\mathrm{m} \mathrm{h}^{-1}$. Secondly, there are three parallel diffusive processes on the sediment side of the water-sediment interface. The first is the molecular diffusion through water-filled pore spaces in the sediment, quantified by the diffusivity in water $B_{W}$, corrected for the sediment porosity. Bioturbation of sediment solids and sediment pore water is treated as two pseudo-diffusive processes invoking two equivalent bioturbation diffusivities, $\mathrm{B}_{\mathrm{PE}}$ and $\mathrm{B}_{\mathrm{WE}}$ in $\mathrm{m}^{2}$ $\mathrm{h}^{-1}$, respectively. In all three cases the diffusion path length is calculated as the log mean depth of the sediment compartment $\left(h_{E}, m\right)$. The final equation for diffusive water-sediment exchange is given by Eq. 11 in Table 3. Eq. 9 and 10 in this Table show the Dvalues describing the exchange of the contaminants across the water-sediment interface.

Finally, the D-value for degradation processes in the vegetation and sediment compartments may be quantified as the product of compartments volume $\left(\mathrm{V}_{\mathrm{V}}\right.$ and $\left.\mathrm{V}_{\mathrm{E}}, \mathrm{m}^{3}\right)$, the compartment $\mathrm{Z}$-value and the degradation rate constants $\left(\mathrm{k}_{\mathrm{RV}}\right.$ and $\left.\mathrm{k}_{\mathrm{RE}}, \mathrm{h}^{-1}\right)$ as given by Eq. 15 and 16 in Table 3.

\section{CONCLUSION}

A comprehensive multimedia agricultural model, MAM, has been developed that described the processes of NVOCs transport and transformation in the agroecosystem. MAM is a Level IV aquivalence-based model, an improved and expanded version of the model that has been described by Batiha et al. ${ }^{[18]}$. Major differences from the earlier model were the increased number of environmental compartments (sediment and vegetation) which together are believed to shape the agro-ecosystem. Therefore, MAM has utilized to treat 
five environmental compartments, namely, the air, water, soil, sediment and vegetation. MAM constructed complete steady-state mass balance for air, water and POC. Even though the rates of primary production and POC mineralization are not required for the contaminant mass balance, they were included in MAM calculation to complete and assure the consistency of the mass balance.

\section{ACKNOWLEDGEMENT}

The authors would like to thank the Malaysian Ministry of Science, Technology and Innovation (MOSTI) through project number 03-01-02-SF0302 for funding this study.

\section{REFERENCES}

1. Cousins, I.T. and D. Mackay, 2001. Strategies for including vegetation compartments in multimedia models. Chemosphere, 44: 643-654. DOI: 10.1016/S0045-6535(00)00514-2.

2. Diamond, M.L., D.A. Priemer and N.L. Law, 2001. Developing a multimedia model of chemical dynamics in urban area. Chemosphere, 44: 16551667. Doi: $10.1016 / \mathrm{S} 0045-6535(00) 00509-9$

3. Hung, H. and D. Mackay, 1997. A novel and simple model of the uptake of organic chemicals by vegetation from air and soil. Chemosphere, 35: 959-977. doi: 10.1016/S0045-6535(97)00182-3

4. Severinsen, M. and T. Jager, 1998. Modelling the influence of terrestrial vegetation on the environmental date of xenobiotics. Chemosphere, 37: 41-62. Doi: 10.1016/S0045-6535(98)80002-7.

5. Buckley, E.H., 1982. Accumulation of airborne polychlorinated biphenyls in foliage. Science, 216: 520-522. Doi: 10.1126/science.216.4545.520.

6. Riederer, M. and J. Schönherr, 1984. Accumulation and transport of (2, 4-dichlorophenoxy) acetic acid in plant cuticles: I sorption in the cuticular membrane and its components. Ecotox. Environ. Safe., $\quad$ 8: 236-247. http://www.ncbi.nlm.nih.gov/pubmed/6734501

7. Taylor, Jr G.E. and J.V.H. Constable, 1994. Modelling Pollutant Deposition to Vegetation: Scaling Down from the Canopy to the Biochemical Level. In: Air Pollutants and the Leaf Cuticle, Percy, K.E., J.N. Cape, R. Jagels and C.J. Simpson (Eds.). Springer, Berlin, Heidelberg, pp: 15-37. ISBN: 0387581464, 3540581464

8. Horstmann, M. and M.S. McLachlan, 1998. Atmospheric deposition of semivolatile organic compounds to two forest canopies. Atmos.
Environ., 32: 1799-1809. Doi: 10.1016/S13522310(97)00477-9.

9. Kujawa, M., M. Raab and W. Haberland, 1995. Environmental levels of PCDD/PCDF in soils of Brandenburg, Germany. Organohalogen Comp., 24: 319-321.

10. Rotard, W., W. Christmann and W. Knoth, 1994. Background levels of PCDD/F in soils of Germany. Chemosphere, 29: 2193-2200. http://cat.inist.fr/?aModele $=$ afficheN\&cpsidt $=3342$ 122

11. Horstmann, M., U. Bopp and M.S. McLachlan, 1997. Comparison of the bulk deposition of $\mathrm{PCDD} / \mathrm{Fs}$ in a spruce forest and an adjacent clearing. Chemosphere, 34: 1245-1254. Doi: 10.1016/S0045-6535(97)00422-0

12. Horstmann, M. and M.S. McLachlan, 1997. Sampling bulk deposition of polychlorinated dibenzo-p-dioxins and dibenzofurans. Atmos. Environ., 31: 2977-2982. Doi: 10.1016/S13522310(97)00106-4

13. McLachlan, M.S., K. Welsch-Pausch and J. Tolls, 1995. Field validation of a model of the uptake of gaseous SOC in Lolium multiflorium (rye grass). Environ. Sci. Technol., 29: 1998-2004. Doi: 10.1021/es00008a018

14. Sehmel, G.A., 1980. Particle and gas dry deposition: A Rev. Atmos. Environ., 14: 983-1011. Doi: 10.1016/0004-6981(80)90031-1

15. Jonas, R. and K. Heinemann, 1985. Studies on the dry deposition of aerosol particles on vegetation and plane surfaces. Aerosol. Sci., 16: 463-471. Doi: 10.1016/0021-8502(85)90058-8.

16. Mackay, D., A. Di Guardo, S. Paterson and C.E. Cowan, 1996. Evaluating the environmental fate of a variety of types of chemicals using the EQC model. Environ. Toxicol. Chem., 15: 1627-1637. Doi: 10.1897/1551-5028(1996) $015<1627$ :ETEFOA $>2.3$. CO, 2

17. Mackay, D., 2001. Multimedia Environmental Models: The Fugacity Approach. 2nd Edn. Lewis Publishers, Boca Raton. ISBN: 13: 9781566705424

18. Batiha, M.A., A.A.H. Kadhum, F. Zahedi, M. Abu Bakar, W.R. Wan Daud, M.S. Takriff and M.M. Batiha, 2007. The fate of non-volatile organic chemicals in the agricultural environment. Am. J. Applied Sci., 2: 456-464. www.scipub.org/scipub/c4p.php?j_id=ajas

19. Wania, F., K. Breivik, N.J. Persson and M.S. McLachlan, 2006. CoZMo-POP 2-A 
fugacity-based dynamic multi-compartmental mass balance model of the fate of persistent organic pollutants. Environ. Modell. Softw., 21: 868-884. Doi: 10.1016/j.envsoft.2005.04.003.

20. Schönherr, J. and M. Riederer, 1989. Foliar Penetration and Accumulation or Organic Chemicals in Plant Cuticles. Rev. Environ. Contam. Toxicol., 108: 1-70. http://www.fao.org/agris/search/display.do?f=./198 9/v1511/DE89U0056.xml;DE89U0056

21. Sabljic, A., H. Gusten, J. Schönherr and M. Riederer, 1990. Modeling plant uptake of airborne organic chemicals. 1. Plant cuticle/water partitioning and molecular connectivity. Environ. Sci. Technol., 24: 1321-1326. Doi: 0013936X/90/0924-1321\$02.50/0

22. Bennett, D., T. Mckone, M. Matthies and W. Kastenberg, 1998. General formulation of characteristic travel distance for semivolatile organic chemicals in a multimedia environment. Environ. Sci. Technol., 32: 4023-4030. Doi: 10.1021/es980328g.
23. Wania, F. and M.S. McLachlan, 2001. Estimating the influence of forests on the overall fate of semivolatile organic compounds using a multimedia fate model. Environ. Sci. Technol., 35: 582-590. Doi: 10.1021/es0011919.

24. Müller, H. and G. Pröhl, 1993. A dynamic model for assessing radiological consequences of nuclear accidents. Health Phys., 64: 232-252. www.healthphysics.com.

25. Whicker, F.W. and T.B. Kirchner, 1987. Pathway: A dynamic food-chain model to predict radionuclide ingestion after fallout deposition. Health Phys., 52: 717-737. http://www.osti.gov/energycitations/product.biblio. jsp?osti_id $=6272858$ 